Article

\title{
Protecting-Group-Free Synthesis of 2-Deoxy-Aza-Sugars
}

\section{Emma Marie Dangerfield ${ }^{1,2}$, Catherine Heather Plunkett ${ }^{1,2}$, Bridget Louise Stocker ${ }^{1, *}$ and Mattie Simon Maria Timmer ${ }^{2, *}$}

1 Malaghan Institute of Medical Research, P.O. Box 7060, Wellington, New Zealand

2 School of Chemical and Physical Sciences, Victoria University of Wellington, P.O. Box 600, Wellington, New Zealand

* Authors to whom correspondence should be addressed; E-Mail: bstocker@malaghan.org.nz (B.L.S.); mattie.timmer@vuw.ac.nz (M.S.M.T.).

Received: 13 November 2009; in revised form: 15 December 2009 / Accepted: 15 December 2009 / Published: 16 December 2009

\begin{abstract}
The protecting-group-free asymmetric synthesis of 1,2,4-trideoxy-1,4-imino-Lxylitol is readily achieved in five steps from 2-deoxy-D-ribose and with an overall yield of $48 \%$. Key in this synthesis is the application of our recently developed Vasella-reductive amination and carbamate annulation methodologies to the synthesis of 2-deoxy-aza-sugars. The carbamate annulation occurred with excellent yield and diastereoselectively $(>20: 1$ d.r.), in favour of the 3,4-cis isomer.
\end{abstract}

Keywords: aza-sugar; glycosidase inhibitors; asymmetric; reductive amination; carbamate

\section{Introduction}

Aza-sugars (also known as imino-sugars) are mimetics of native sugars whereby the ring oxygen is replaced by a nitrogen atom. Due to their structural similarity to native carbohydrates, aza-sugars are able to act as glycosidase inhibitors and therefore have enormous therapeutic potential in the treatment of a variety of diseases including viral infection, bacterial infection, lysosomal storage disorders, cancer and diabetes [1-9]. Indeed, the use of Zavesca ${ }^{\circledR}$ for the treatment of Gaucher's disease marked the launch of the first aza-sugar medication [10].

In view of the growing biological importance of aza-sugars, our interest has been in the development of new methodologies for the diastereoselective synthesis of this class of compounds [11]. In particular, our focus has been on the synthesis of 3,4-cis-substituted aza-sugars (Figure 1), 
which include family members such as the antibiotic Anisomycin (1) [12], the potent mannosidase inhibitor 1,4-dideoxy-1,4-imino-D-mannitol (2) [13], adamantyl substituted 2,5-anhydro-2,5-imino-Dglucitol 3, a promising molecular chaperone in the treatment of Gaucher's disease [14], the $\alpha$-galactosidase inhibitor 1,4-dideoxy-1,4-imino-D-lyxitol (4) [15] and its L-isomer, 1,4-dideoxy-1,4imino-L-lyxitol (5) [16]. Even in recent years, novel pyrrolidines, such as 1,4-dideoxy-1,4-imino-Dxylitol (6), are still being isolated from natural products [17].

Figure 1. Representative pyrrolidines containing the 3,4-cis substituted core.

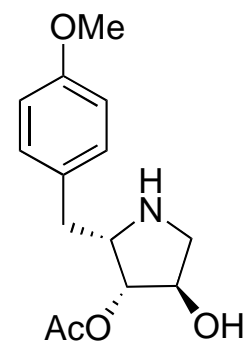

1

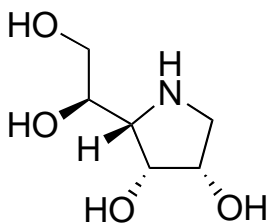

2

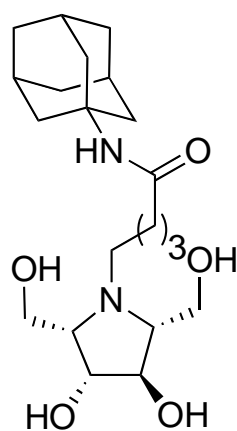

3

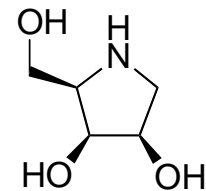

4

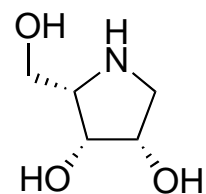

5

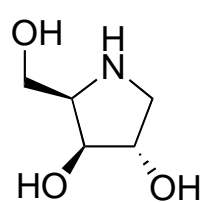

6

Due to the limited biological availability of many aza-sugars, only few have been widely studied for their therapeutic potential. The ability to rapidly and efficiently synthesise aza-sugars therefore represents an enormous potential for full assessment of their biological profiles. The methodology we developed for the synthesis of 3,4-cis-substituted aza-sugars involves a protecting-group-free strategy whereby readily available carbohydrate precursors are transformed into 3,4-cis-substituted aza-sugars via use of a Vasella-reductive amination protocol and a novel carbamate annulation reaction [11]. Our strategy is not merely competitive in yield and number of linear-steps, but also employs many of the principles of Green Chemistry (i.e., atom economy, reactions in aqueous media), and has been applied to the synthesis of 1,4-dideoxy-1,4-imino-L-lyxitol (5) and 1,4-dideoxy-1,4-imino-D-xylitol (6), each synthesised in five steps and in 55\% and 57\% overall yield, respectively. We now wish to report on the extension of our methodology for the synthesis of 2-deoxy-aza-sugars and to provide further explanation for the remarkable diastereoselectivity observed in our carbamate annulation reaction.

\section{Results and Discussion}

The retrosynthesis of our target aza-sugar, 1,2,4-trideoxy-1,4-imino-L-xylitol (7), is presented in Scheme 1 . Here, the pyrrolidine $\mathbf{7}$ is prepared via the hydrolysis of carbamate $\mathbf{8}$, which is itself formed via an iodine-promoted halocyclization/in situ carbonylation reaction. The linear amino alcohol $\mathbf{9}$ is in turn accessible via the reductive amination of hydroxyaldehydes obtained following Vasella reaction of methyl iodofuranosides 10, prepared in two steps from 2-deoxy-D-ribose. As can be seen, this synthetic route is short and efficient, and can be accomplished without the use of protecting groups. It is anticipated that the C-3 stereogenic centre in 2-deoxy-D-ribose will be key in determining the stereochemistry of carbamate $\mathbf{8}$, and hence the final pyrrolidine $\mathbf{7}$. 
Scheme 1. Retrosynthesis for the formation of 1,2,4-trideoxy-1,4-imino-L-xylitol.<smiles>OC[C@H]1NCC[C@H]1O</smiles>

7<smiles>O=C1OC[C@H]2[C@@H](O)CCN12</smiles>

8

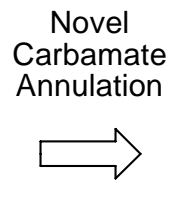<smiles>CCC[C@H](O)CCN</smiles>

9<smiles>CO[C@@H]1C[C@@H](O)[C@@H](CI)O1</smiles>

10

With our synthetic strategy in place, synthesis of 2-deoxy-aza-L-xylitol commenced with the formation of methyl glycoside 12 from 2-deoxy-D-ribose (11) under standard Fischer glycosidation conditions (Scheme 2). Given the propensity of 2-deoxy-D-ribose to form the thermodynamically more stable pyranose ring, short reaction times were required to favour formation of the desired furanoside. Thus, in accordance with a procedure by Hoffer and co-workers [18], 2-deoxy-D-ribose was subjected to $1 \% \mathrm{AcCl}$ in $\mathrm{MeOH}$ for $15 \mathrm{~min}$, resulting in almost exclusive formation of 2-deoxy-D-ribofuranoside 12 with only trace amounts ( $c a .5 \%$ ) of the pyranose structural isomer. Installation of an iodide at the primary position was then attempted by refluxing a solution of methyl 2-deoxy-D-ribose 12, triphenylphosphine, $\mathrm{I}_{2}$ and imidazole in THF for $2 \mathrm{hr}$. Unfortunately, these conditions led to significant degradation, however milder reaction conditions, involving stirring the same reagents at room temperature for $18 \mathrm{hr}$ [19], allowed for the preparation of methyl 2,5-dideoxy-5-iodo-D-riboside (10) in satisfactory yield $(73 \%)$.

Scheme 2. Synthesis of 1,2,4-trideoxy-1,4-imino-L-xylitol.<smiles>OCC1O[C@@H](O)C[C@@H]1O</smiles>

11<smiles>OC[C@@H]1NCC[C@@H]1O</smiles>

7

(1)

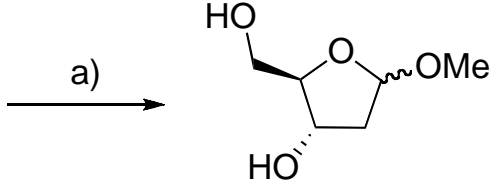

12

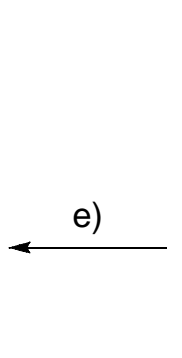

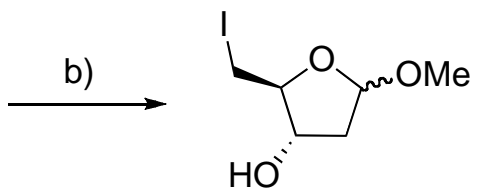

10

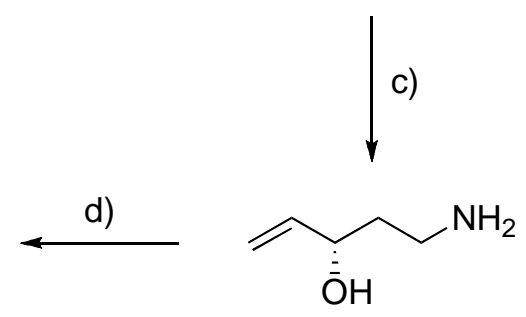

9

Reagents and Conditions: a) $1 \% \mathrm{AcCl}$ in $\mathrm{MeOH}, \mathrm{rt}, 15 \mathrm{~min}, 91 \%$; b) $\mathrm{PPh}_{3}, \mathrm{I}_{2}$, imidazole, rt, $18 \mathrm{hr}$, $73 \%$; c) Zn, EtOH, $\mathrm{NH}_{4} \mathrm{OAc}, \mathrm{NH}_{3}$ (aq.), $\mathrm{NaCNBH}_{3}$, reflux, 18 hr, 81\%; d) $\mathrm{I}_{2}, \mathrm{NaHCO}_{3}, \mathrm{H}_{2} \mathrm{O}$, rt, 18 hr, $90 \%$; e) $\mathrm{NaOH}, \mathrm{EtOH}$, reflux, 2 hr, $99 \%$.

With the key methyl iodoglycoside precursor $\mathbf{1 0}$ in hand, we were then able to investigate the applicability of our Vasella-reductive amination conditions to the synthesis of linear alkenylamines without a substituent at the C-2 position. Previously we reported that primary amines containing 
hydroxy groups at C-2 and C-3 can be prepared in one step from the corresponding methyl iodoglycoside [3]. Key in this reaction was the use of saturated $\mathrm{NH}_{4} \mathrm{OAc}$ in buffered conditions for the Vasella-reductive amination. Such conditions allow for the preferential formation of the desired primary amine over the formation of the undesired secondary amine, which can occur if the primary amine undergoes a second reductive amination reaction with another molecule of aldehyde (formed in the Vasella reductive ring opening). With an interest in exploring the scope of this reaction, we subjected methyl iodo-glycoside 10 to a suspension of $\mathrm{Zn}, \mathrm{NH}_{4} \mathrm{OAc}, \mathrm{NH}_{3}$ and $\mathrm{NaCNBH}_{3}$ in ethanol at reflux (Scheme 2). Upon completion of the reaction, as indicated by TLC, the reaction was concentrated and acidified, using isopropanol and hydrochloric acid, and the residue purified using a Dowex $\left(\mathrm{H}^{+}\right)$column, according to our previously published protocols [3]. These conditions led to the isolation of the desired alkenylamine 9 in $c a .70 \%$ yield, though the sample was contaminated with an undesired by-product, 1,5-diaminopent-2-ene (ca. 10\%) as evidenced by a mass of $101.1082\left[\mathrm{M}+\mathrm{H}^{+}\right]$, the presence of an internal olefin $\left({ }^{13} \mathrm{C}\right.$ NMR $\delta 132.4$ and $\delta$ 124.8) and $\mathrm{HMBC}$ between $\mathrm{C} 3$ and $\mathrm{H} 2, \mathrm{H} 1$ and $\mathrm{H} 5, \mathrm{C} 4$ and $\mathrm{H} 2$ and $\mathrm{H} 5, \mathrm{C} 1$ and $\mathrm{H} 2$, and $\mathrm{C} 2$ and $\mathrm{H} 1$, and with no $\mathrm{HMBC}$ between $\mathrm{C} 5$ and $\mathrm{H} 2$ or H1. It is proposed that this by-product was formed via displacement of the allylic hydroxyl of 9 following protonation upon work-up and nucleophilic attack by ammonia at the allylic position. Accordingly, a milder work-up procedure was performed, involving co-evaporation of the reaction mixture in vacuo with isopropanol, to remove the majority of the ammonium acetate salts, loading of the residue directly onto a Dowex $\left(\mathrm{H}^{+}\right)$column and elution with aqueous ammonia. Using this protocol, linear alkenylamine 9 was isolated in good (81\%) yield and with no trace of the diamino byproduct. Having illustrated that our modified Vasella-reductive amination conditions are also applicable to the synthesis of C-2 unsubstituted alkenylamines, alkenylamine 9 was then subjected to an iodine-promoted carbamate annulation (Scheme 2). To our delight, this reaction proceeded smoothly and gave the desired carbamate $\mathbf{8}$ in quantitative yield and with a diastereoselectivity of greater than 20:1 in favour of the 3,4-cis isomer, as determined by ${ }^{1} \mathrm{H}$ NMR of the crude reaction mixture. The hydrolysis of carbamate 8 using $\mathrm{NaOH}$ proceeded uneventfully and quantitatively gave the desired pyrrolidine 7 , as confirmed via comparison of spectral data with that previously reported [20-23]. In sum, we have been able to prepare 1,2,4-trideoxy-1,4-imino-L-xylitol in 5 steps, from cheap and readily available 2-deoxy-ribose, in an overall yield of $48 \%$, the shortest and highest yielding route reported to date.

Perhaps one of the most remarkable features of our strategy for the synthesis of pyrrolidines is the high yield and diastereoselectivity observed in the carbamate annulation reaction. The diastereoselectivity is in favour of the 3,4-cis isomer, as illustrated by formation of 2-deoxy L-xylo carbamate 8 (entry 1, Table 1), L-lyxo carbamate 14 (entry 2) and D-xylo carbamate 16 (entry 3) [11] from alkenylamines 7, 13, and 15, respectively. From these results it is apparent that the stereochemistry at the $\mathrm{C}-3$ position exerts stereocontrol on the cyclisation reaction and is independent of the stereochemistry, or lack of stereochemistry, at the C-2 position. 
Table 1. Diastereoselectivity of iodine-promoted carbamate annulations.

\begin{tabular}{|c|c|c|c|c|}
\hline Entry & Alkenylamine & Carbamate & Diastereoselectivity & Yield $^{\mathrm{a}}$ \\
\hline 1 & HO & $\mathrm{HO}^{\circ} \quad 8$ & $>20: 1$ & $95 \%$ \\
\hline $2^{b}$ & $\mathrm{HO}_{13} \mathrm{OH}$ & $\mathrm{HO}_{14}$ & $>20: 1$ & $93 \%$ \\
\hline $3^{b}$ & $\mathrm{HO}_{15}$ & & $>20: 1$ & $99 \%$ \\
\hline
\end{tabular}

${ }^{\mathrm{a}}$ Isolated yield. ${ }^{\mathrm{b}}$ See reference [11].

The high diastereoselectivity observed in these cyclisation reactions can be explained via a transition state model originally proposed by Chamberlin et al. [24-26] and in line with theoretical studies by Gouverneur and co-workers [27]. Attack of the amine on the $\mathrm{I}_{2}$-ethylene complex is envisioned to take place via a 5-membered ring transition structure, in which the ring nitrogen approaches the double bond in an ${ }^{\mathrm{N}} E$ (envelope) conformation, and follows a Bürgi-Dunitz-like trajectory [28] (Figure 2). The hydroxyl substituent on the ring can now be positioned either in the plane of the double bond (A, O-in-plane), or almost perpendicular to that plane (B, H-in-plane). Of these two transition states, $\mathbf{A}$ has minimal overlap between the electron-withdrawing $\sigma_{\mathrm{C}-\mathrm{O}}^{*}$ and reacting $\pi_{\mathrm{C}=\mathrm{C}}$ orbitals, thereby forming the lowest energy transition state. The H-in-plane structure (B) has overlapping hydroxyl $\sigma_{\mathrm{C}-\mathrm{O}}^{*}$ and double bond $\pi_{\mathrm{C}=\mathrm{C}}$ orbitals, which destabilises the $\mathrm{I}_{2}-\pi$ complex and is hence disfavoured.

Figure 2. Proposed transition state for iodine-promoted carbamate annulation.

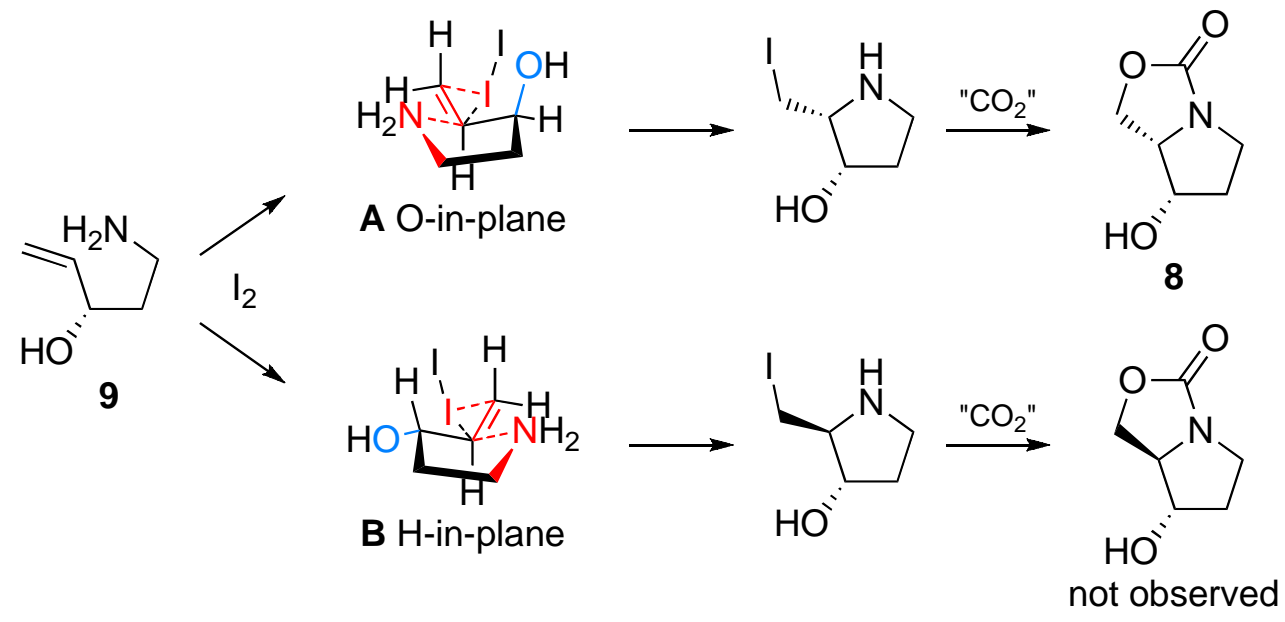




\section{Experimental}

\section{General procedures}

Unless otherwise stated all reactions were performed under atmospheric air. THF (Lab-Scan) was distilled from $\mathrm{LiAlH}_{4}$ prior to use. $\mathrm{H}_{2} \mathrm{O}, \mathrm{MeOH}$ (Pure Science), EtOAc (Pure Science), and Hexanes (Pure Science) were distilled prior to use. EtOH (absolute, Pure Science), AcOH (Ajax Finechem), DCM (LabServ), 30\% aqueous $\mathrm{NH}_{3}$ (J. T. Baker Chemical Co.), $\mathrm{Et}_{2} \mathrm{O}$ (Merck), 2-deoxy-D-ribose (Fluka), $\mathrm{AcCl}$ (B\&M), $\mathrm{PPh}_{3}$ (Merck), Imidazole (Aldrich), $\mathrm{I}_{2}(\mathrm{BDH}), \mathrm{NaCNBH}_{3}$ (Aldrich), $\mathrm{NaOH}$ (Pure Science), and $\mathrm{NH}_{4} \mathrm{OAc}$ (AnalaR) were used as received. $\mathrm{Zn}$ dust was activated by the careful addition of conc. $\mathrm{H}_{2} \mathrm{SO}_{4}$ washed with EtOH (3x) and hexanes (3x), and stored under dry hexanes. All solvents were removed by evaporation under reduced pressure. Reactions were monitored by TLCanalysis on Macherey-Nagel silica gel coated plastic sheets $\left(0.20 \mathrm{~mm}\right.$, Polygram SIL G/UV $\left.\mathrm{UV}_{254}\right)$ with detection by UV-absorption (254 nm), by spraying with $20 \% \mathrm{H}_{2} \mathrm{SO}_{4}$ in $\mathrm{EtOH}$ followed by charring at $\sim 150{ }^{\circ} \mathrm{C}$, by dipping in $\mathrm{I}_{2}$ in silica, or by spraying with a solution of ninhydrin in $\mathrm{EtOH}$ followed by charring at $\sim 150{ }^{\circ} \mathrm{C}$. Column chromatography was performed on Pure Science silica gel (40-63 micron). Dowex ${ }^{\circledR}$ W50-X8 acidic resin (Sigma) and Dowex ${ }^{\circledR} 1$ X4-50 basic resin (Sigma) were used for ion exchange chromatography and HP20 (Supelco) for reverse phase chromatography. Highresolution mass spectra were recorded on a Waters Q-TOF Premier ${ }^{\mathrm{TM}}$ Tandem Mass Spectrometer using positive electro-spray ionisation. Optical rotations were recorded using a Perkin-Elmer 241 polarimeter at the sodium D-line. Infrared spectra were recorded as thin films using a Bruker Tensor 27 FTIR spectrometer, equipped with an Attenuated Total Reflectance (ATR) sampling accessory, and are reported in wave numbers $\left(\mathrm{cm}^{-1}\right)$. Nuclear magnetic resonance spectra were recorded at $20{ }^{\circ} \mathrm{C}$ in $\mathrm{D}_{2} \mathrm{O}, \mathrm{CD}_{3} \mathrm{OD}$, or $\mathrm{CDCl}_{3}$ using either a Varian Unity-INOVA operating at $300 \mathrm{MHz}$ or a Varian Unity operating at $500 \mathrm{MHz}$. Chemical shifts are given in ppm ( $\delta$ ) relative to tetramethylsilane. NMR peak assignments were made using COSY, HSQC and HMBC experiments.

Methyl 2-deoxy- $\alpha / \beta$-D-riboside (12). To a solution of 2-deoxy-D-ribose (11, $200 \mathrm{mg}, 1.5 \mathrm{mmol}) \mathrm{in}$ $\mathrm{MeOH}(3.6 \mathrm{~mL}), \mathrm{AcCl}(100 \mu \mathrm{L})$ was added and the reaction was stirred at room temperature for $15 \mathrm{~min}$. The reaction was neutralised by the addition of Dowex $\left(\mathrm{OH}^{-}\right)$, filtered and concentrated. The resulting oil was purified by gradient flash ch romatography (EtOAc $\rightarrow \mathrm{MeOH} / \mathrm{EtOAc}, 1 / 9$, v/v) to give methyl furanoside $12(203 \mathrm{mg}, 1.37 \mathrm{mmol}, 91 \%) . \mathrm{R}_{f}=0.7\left(15 \% \mathrm{MeOH}\right.$ in EtOAc); $[\alpha]_{\mathrm{D}}{ }^{18}=$ +5.20 (c = 1.0, EtOH); IR (film), 3372, 2942, 1448, 1358, 1031, $1009 \mathrm{~cm}^{-1}$; ${ }^{1} \mathrm{H}-\mathrm{NMR}$ (500 MHz, $\left.\mathrm{CDCl}_{3}\right) \delta 5.17\left(\mathrm{dd}, J_{1,2 \mathrm{~b}}=2.1, J_{1,2 \mathrm{a}}=5.5 \mathrm{~Hz}, 1 \mathrm{H}, \mathrm{H}-1 \beta\right), 5.12\left(\mathrm{dd}, J_{1,2 \mathrm{~b}}=2.3, J_{1,2 \mathrm{a}}=4.4 \mathrm{~Hz} 1 \mathrm{H}, \mathrm{H}-1 \alpha\right)$,

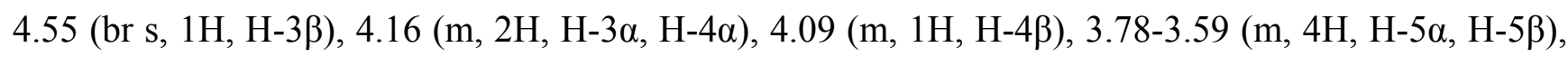
$3.41(\mathrm{~s}, 3 \mathrm{H}$, OMe- $\alpha), 3.40$ (s, 3H, OMe- $\beta$ ), $2.32\left(\mathrm{ddd}, J_{1,2 \mathrm{a}}=2.3, J_{2 \mathrm{a}, 3}=4.9, J_{2 \mathrm{a}, 2 \mathrm{~b}}=14.0 \mathrm{~Hz}, 1 \mathrm{H}, \mathrm{H}-\right.$ $2 \mathrm{a} \alpha), 2.18-2.09$ (m, 2H, H-2b $\alpha, \mathrm{H}-2 \mathrm{a} \beta), 2.05-2.02(\mathrm{~m}, 1 \mathrm{H}, \mathrm{H}-2 \mathrm{~b} \beta) ;{ }^{13} \mathrm{C}-\mathrm{NMR}\left(125 \mathrm{MHz}, \mathrm{CDCl}_{3}\right) \delta$ $105.7(\mathrm{C} 1-\beta), 105.6(\mathrm{C} 1-\alpha), 87.8(\mathrm{C} 4-\beta), 87.6(\mathrm{C} 4-\alpha), 73.0(\mathrm{C} 3-\beta), 72.3(\mathrm{C} 3-\alpha), 63.6(\mathrm{C} 5-\beta), 63.3$ $(\mathrm{C} 5-\alpha), 55.6(\mathrm{OMe}-\beta), 55.0(\mathrm{OMe}-\alpha), 42.8(\mathrm{C} 2-\beta), 41.7$ (C2- $\alpha)$; HRMS(ESI) $m / z$ calcd. for $\left[\mathrm{C}_{6} \mathrm{H}_{12} \mathrm{O}_{4} \mathrm{Na}\right]^{+}: 171.0633$, obsd.:171.0631. 
Methyl 2,5-dideoxy-5-iodo- $\alpha / \beta$-D-riboside (10). To a solution of methyl 2-deoxy- $\alpha / \beta$-D-riboside (12, $200 \mathrm{mg}, 1.3 \mathrm{mmol})$ in dry THF (6.5 mL) under an atmosphere of nitrogen, $\mathrm{PPh}_{3}(524 \mathrm{mg}, 2.0 \mathrm{mmol})$, imidazole (177 mg, $2.6 \mathrm{mmol})$ and $\mathrm{I}_{2}(504 \mathrm{mg}, 2.0 \mathrm{mmol})$ were added. The reaction was stirred at room temperature for 18 hours then filtered and concentrated. The residue was purified by gradient flash chromatography (EtOAc $\rightarrow \mathrm{MeOH} /$ EtOAc, 1/10, v/v) to give the pure methyl 2,5-dideoxy-5iodo-D-riboside 10. (257 mg, $0.99 \mathrm{mmol}, 73 \%)$. $\mathrm{R}_{f}=0.6\left(15 \% \mathrm{MeOH}\right.$ in EtOAc); $[\alpha]_{\mathrm{D}}{ }^{17}=-2.05$ (c = 1.0, $\mathrm{CHCl}_{3}$ ); IR (film), 3475, 2986, 2874, 2829, 1416, 1441, 1062, $1016 \mathrm{~cm}^{-1}$; ${ }^{1} \mathrm{H}-\mathrm{NMR}(500$ $\left.\mathrm{MHz} \mathrm{CDCl}_{3}\right) \delta 5.14\left(\mathrm{~d}, J_{1,2 \mathrm{~b}}=4.5 \mathrm{~Hz}, 1 \mathrm{H}, \mathrm{H}-1 \beta\right), 5.12\left(\mathrm{dd}, J_{1,2 \mathrm{~b}}=1.6, J_{1,2 \mathrm{a}}=5.2 \mathrm{~Hz} 1 \mathrm{H}, \mathrm{H}-1 \alpha\right), 4.49$ $\left(\mathrm{ddd}, J_{2 \mathrm{a}, 3}=4.1, J_{2 \mathrm{~b}, 3}=6.6, J_{3,4}=10.7 \mathrm{~Hz}, 1 \mathrm{H}, \mathrm{H}-3 \beta\right), 4.14(\mathrm{~m}, 3 \mathrm{H}, \mathrm{H}-3 \alpha, \mathrm{H}-4 \beta, \mathrm{H}-4 \alpha), 3.39$ (s, 3H, OMe- $\beta$ ), 3.36 (s, $3 \mathrm{H}$, OMe- $\alpha$ ), $3.32\left(\mathrm{dd}, J_{4,5 \mathrm{a}}=5.8, J_{5 \mathrm{a}, 5 \mathrm{~b}}=9.5 \mathrm{~Hz}, 1 \mathrm{H}, \mathrm{H}-5 \mathrm{a} \beta\right), 3.26$ (dd, $J_{5 \mathrm{a}, 4}=4.9$, $\left.J_{5 \mathrm{a}, 5 \mathrm{~b}}=10.5 \mathrm{~Hz}, 1 \mathrm{H}, \mathrm{H}-5 \mathrm{a} \alpha\right), 3.20\left(\mathrm{t}, J_{5 \mathrm{a}, 5 \mathrm{~b}}=J_{4,5 \mathrm{~b}}=9.5 \mathrm{~Hz}, 1 \mathrm{H}, \mathrm{H}-5 \mathrm{~b} \beta\right), 3.18\left(\mathrm{dd}, J_{4,5 \mathrm{~b}}=6.3, J_{5 \mathrm{a}, 5 \mathrm{~b}}=\right.$ $10.5 \mathrm{~Hz}, 1 \mathrm{H}, \mathrm{H}-5 \mathrm{~b} \alpha$ ), 2.32 (ddd, $\left.J_{1,2 \mathrm{~b}}=1.6, J_{2 \mathrm{~b}, 3}=6.8, J_{2 \mathrm{a}, 2 \mathrm{~b}}=13.5 \mathrm{~Hz}, 1 \mathrm{H}, \mathrm{H}-2 \mathrm{a} \alpha\right), 2.23$ (ddd, $J_{1,2 \mathrm{~b}}=$ $\left.4.5, J_{2 \mathrm{~b}, 3}=6.6, J_{2 \mathrm{a}, 2 \mathrm{~b}}=14.2 \mathrm{~Hz}, 1 \mathrm{H}, \mathrm{H}-2 \mathrm{~b} \beta\right), 2.13\left(\mathrm{td}, J_{1,2 \mathrm{a}}=J_{2 \mathrm{a}, 3}=5.2, J_{2 \mathrm{a}, 2 \mathrm{~b}}=13.5 \mathrm{~Hz}, 1 \mathrm{H}, \mathrm{H}-2 \mathrm{~b} \alpha\right)$, $2.00\left(\mathrm{dd}, J_{2 \mathrm{a}, 3}=4.1, J_{2 \mathrm{a}, 2 \mathrm{~b}}=14.2 \mathrm{~Hz}, 1 \mathrm{H}, \mathrm{H}-2 \mathrm{a} \beta\right) ;{ }^{13} \mathrm{C}-\mathrm{NMR}\left(125 \mathrm{MHz}, \mathrm{CDCl}_{3}\right) \delta 105.8(\mathrm{C} 1-\beta), 105.4$ $(\mathrm{C} 1-\alpha), 86.2$ (C4- $\beta$ ), $86.0(\mathrm{C} 4-\alpha), 75.8(\mathrm{C} 3-\beta), 75.6$ (C3- $\alpha$ ), 55.3 (OMe- $\beta$ ), 55.1 (OMe- $\alpha), 41.9$ (C2- $\beta$ ), $40.9(\mathrm{C} 2-\alpha), 7.9(\mathrm{C} 5-\beta), 6.7(\mathrm{C} 5-\alpha) ; \mathrm{HRMS}(\mathrm{ESI}) \mathrm{m} / \mathrm{z}$ calcd. for $\left[\mathrm{C}_{6} \mathrm{H}_{11} \mathrm{O}_{3} \mathrm{INa}\right]^{+}: 280.9651$, obsd.:280.9655.

(S)-5-Amino-pent-1-en-3-ol hydrochloride (9). To a solution of methyl 2,5-dideoxy-5-iodo- $\alpha / \beta-D-$ riboside $(10,100 \mathrm{mg}, 0.38 \mathrm{mmol})$ in a saturated solution of $\mathrm{NH}_{4} \mathrm{OAc}$ in $\mathrm{EtOH}(7.6 \mathrm{~mL})$ was added activated $\mathrm{Zn}$ (124 mg, $1.9 \mathrm{mmol}), \mathrm{NaCNBH}_{3}(48 \mathrm{mg}, 0.76 \mathrm{mmol})$ and $30 \%$ aqueous $\mathrm{NH}_{3}(3 \mathrm{~mL})$. The mixture was stirred at reflux for $18 \mathrm{~h}$, cooled to room temperature and concentrated under reduced pressure. The residue was redissolved in $i \mathrm{PrOH}$ and concentrated. The suspension was purified directly using Dowex $\left(\mathrm{H}^{+}\right)$. The product was eluted in 5 to $15 \%$ aqueous $\mathrm{NH}_{3}$, and the free base was converted into the $\mathrm{HCl}$ salt $(\mathrm{HCl}$ in isopropanol) to give pure alkenylamine hydrochloride 9 (42 $\mathrm{mg}, 0.31 \mathrm{mmol}$, $81 \%) . \mathrm{R}_{f}=0.4\left(\mathrm{DCM} / \mathrm{EtOH} / \mathrm{MeOH} / 30 \%\right.$ aqueous $\left.\mathrm{NH}_{3}, 5 / 2 / 2 / 1, \mathrm{v} / \mathrm{v} / \mathrm{v} / \mathrm{v}\right) ;[\alpha]_{\mathrm{D}}{ }^{17}=-3.2(\mathrm{c}=0.1$, EtOH); IR (film), 3359, 3047, 2955, 2927, 2854, 1635, 1428, 1134, $1056 \mathrm{~cm}^{-1} ;{ }^{1} \mathrm{H}-\mathrm{NMR}$ (300 MHz, $\left.\mathrm{D}_{2} \mathrm{O}\right) \delta 5.35\left(\mathrm{ddd}, J_{3,4}=6.1, J_{4,5 \mathrm{~b}}=10.5, J_{4,5 \mathrm{a}}=17.3 \mathrm{~Hz}, 1 \mathrm{H}, \mathrm{H} 4\right), 5.06\left(\mathrm{dd}, J_{5 \mathrm{a}, 5 \mathrm{~b}}=1.3, J_{4,5 \mathrm{a}}=17.3 \mathrm{~Hz}\right.$, $1 \mathrm{H}, \mathrm{H}-5 \mathrm{a}), 5.04\left(\mathrm{dd}, J_{5 \mathrm{a}, 5 \mathrm{~b}}=1.3, J_{4,5 \mathrm{~b}}=10.5 \mathrm{~Hz}, 1 \mathrm{H}, \mathrm{H}-5 \mathrm{~b}\right), 4.04\left(\mathrm{q}, J_{2 \mathrm{a}, 3}=J_{2 \mathrm{~b}, 3}=J_{3,4}=6.1 \mathrm{~Hz}, 1 \mathrm{H}\right.$, H-3), 2.96 (m, 2H, H-1), 1.38 (m, 2H, H-2); ${ }^{13} \mathrm{C}-\mathrm{NMR}$ (75 MHz, $\left.\mathrm{D}_{2} \mathrm{O}\right) \delta 138.8$ (C4), 115.8 (C5), 70.1 (C3), 36.3 (C1), 32.9 (C2). HRMS(ESI) $\mathrm{m} / z$ calcd. for $\left[\mathrm{C}_{5} \mathrm{H}_{12} \mathrm{NO}\right]^{+}: 102.0919$, obsd.:102.0921.

(7S, 7aS)-7-Hydroxy-tetrahydro-pyrrolo[1,2-c]oxazol-3-one (8). To a solution of linear alkenylamine hydrochloride 9 (30 mg, $0.21 \mathrm{mmol})$ in water $(2 \mathrm{~mL})$ was added $\mathrm{NaHCO}_{3}(27 \mathrm{mg}, 0.33 \mathrm{mmol})$ and $\mathrm{I}_{2}$ $(61 \mathrm{mg}, 0.24 \mathrm{mmol})$. The solution was stirred $18 \mathrm{~h}$ at room temperature then filtered and concentrated under reduced pressure. The residue was purified by gradient flash chromatography (EtOAc $\rightarrow$ EtOAc/MeOH, 99/1, v/v) to give carbamate 8 as an amorphous white powder $(27 \mathrm{mg}, 0.19 \mathrm{mmol}$, $90 \%) \cdot[\alpha]_{\mathrm{D}}{ }^{17}=+7.0(c=0.1, \mathrm{EtOH})$; IR (film), 3419, 3385, 3047, 2986, 2931, 1730, 1448, $1087 \mathrm{~cm}^{-1}$; ${ }^{1} \mathrm{H}-\mathrm{NMR}\left(500 \mathrm{MHz}, \mathrm{D}_{2} \mathrm{O}\right) \delta 4.42\left(\mathrm{t}, J_{4,5 \mathrm{a}}=J_{5 \mathrm{a}, 5 \mathrm{~b}}=9.2 \mathrm{~Hz}, 1 \mathrm{H}, \mathrm{H}-5 \mathrm{a}\right), 4.34\left(\mathrm{dd}, J_{4,5 \mathrm{~b}}=3.6\right.$, $\left.J_{5 \mathrm{a}, 5 \mathrm{~b}}=9.2 \mathrm{~Hz}, 1 \mathrm{H}, \mathrm{H}-5 \mathrm{~b}\right), 4.08\left(\mathrm{t}, J_{3,4}=J_{2 \mathrm{a}, 3}=3.6 \mathrm{~Hz}, 1 \mathrm{H}, \mathrm{H}-3\right), 3.90\left(\mathrm{td}, J_{3,4}=J_{4,5 \mathrm{~b}}=3.6, J_{4,5 \mathrm{a}}=9.2\right.$ $\mathrm{Hz}, 1 \mathrm{H}, \mathrm{H}-4), 3.37$ (ddd, $\left.J_{1 \mathrm{a}, 2 \mathrm{~b}}=8.1, J_{1 \mathrm{a}, 2 \mathrm{a}}=9.5, J_{1 \mathrm{a}, 1 \mathrm{~b}}=10.9 \mathrm{~Hz}, 1 \mathrm{H}, \mathrm{H}-1 \mathrm{a}\right), 3.15$ (ddd, $J_{1 \mathrm{~b}, 2 \mathrm{~b}}=2.2$, $\left.J_{1 \mathrm{~b}, 2 \mathrm{a}}=10.0, J_{1 \mathrm{a}, 1 \mathrm{~b}}=10.9 \mathrm{~Hz}, 1 \mathrm{H}, \mathrm{H}-1 \mathrm{~b}\right), 2.06\left(\mathrm{ddd}, J_{1 \mathrm{a}, 2 \mathrm{a}}=9.5, J_{1 \mathrm{~b}, 2 \mathrm{a}}=10.0, J_{2 \mathrm{a}, 2 \mathrm{~b}}=14.2 \mathrm{~Hz}, 1 \mathrm{H}, \mathrm{H}-\right.$ 
2a), $1.93\left(\mathrm{ddd}, J_{1 \mathrm{~b}, 2 \mathrm{~b}}=2.2, J_{1 \mathrm{a}, 2 \mathrm{~b}}=8.1, J_{2 \mathrm{a}, 2 \mathrm{~b}}=14.2 \mathrm{~Hz}, 1 \mathrm{H}, \mathrm{H}-2 \mathrm{~b}\right) ;{ }^{13} \mathrm{C}-\mathrm{NMR}\left(125 \mathrm{MHz}, \mathrm{D}_{2} \mathrm{O}\right) \delta 171.0$ (C6), 69.6 (C3), 64.4 (C4), 64.3 (C5), 43.0 (C1), 33.7 (C2). HRMS(ESI) m/z calcd. for $\left[\mathrm{C}_{6} \mathrm{H}_{9} \mathrm{NO}_{3} \mathrm{Na}\right]^{+}: 166.0486$ obsd.:166.0480.

(2R,3R)-2-(Hydroxymethyl)-3-hydroxypyrrolidine hydrochloride (7). To a solution of carbamate 8 $(10 \mathrm{mg}, 0.07 \mathrm{mmol})$ in absolute $\mathrm{EtOH}(2 \mathrm{~mL})$ was added $\mathrm{NaOH}(28 \mathrm{mg}, 10 \mathrm{mmol})$. The solution was stirred at reflux for $2 \mathrm{~h}$ then cooled and neutralised with Dowex $\left(\mathrm{H}^{+}\right)$. Pyrrolidine 7 was eluted in 5 to $15 \%$ aqueous $\mathrm{NH}_{3}(8.2 \mathrm{mg}, 0.07 \mathrm{mmol}, 99 \%)$. The free base was converted into the $\mathrm{HCl}$ salt using $\mathrm{HCl}$ in isopropanol to give pure hydrochloride. $\mathrm{R}_{f}=0.1$ (DCM/EtOH/MeOH/30\% aqueous $\mathrm{NH}_{3}, 5 / 2 / 2 / 1$, $\mathrm{v} / \mathrm{v} / \mathrm{v} / \mathrm{v}) ;[\alpha]_{\mathrm{D}}{ }^{17}=+10.0(\mathrm{c}=0.09, \mathrm{MeOH}) ;$ IR (film), 3397, 3364, 2960, 2932, 2874, 1720, 1601, 1168, $1064 \mathrm{~cm}^{-1}$; ${ }^{1} \mathrm{H}-\mathrm{NMR}\left(500 \mathrm{MHz}, \mathrm{D}_{2} \mathrm{O}\right) \delta 4.27\left(\mathrm{dt}, J_{2 \mathrm{~b}, 3}=1.5, J_{2 \mathrm{a}, 3}=J_{3,4}=4.9 \mathrm{~Hz}, 1 \mathrm{H}, \mathrm{H} 3\right), 3.98(\mathrm{dd}$, $\left.J_{4,5 \mathrm{a}}=4.9, J_{5 \mathrm{a}, 5 \mathrm{~b}}=12.1 \mathrm{~Hz}, 1 \mathrm{H}, \mathrm{H}-5 \mathrm{a}\right), 3.83\left(\mathrm{dd}, J_{4,5 \mathrm{~b}}=8.5, J_{5 \mathrm{a}, 5 \mathrm{~b}}=12.1 \mathrm{~Hz}, 1 \mathrm{H}, \mathrm{H}-5 \mathrm{~b}\right), 3.31$ (td, $\left.J_{3,4}=J_{4,5 \mathrm{a}}=4.9, J_{4,5 \mathrm{~b}}=8.5 \mathrm{~Hz}, 1 \mathrm{H}, \mathrm{H}-4\right), 3.25\left(\mathrm{ddd}, J_{1 \mathrm{a}, 2 \mathrm{~b}}=7.6, J_{1 \mathrm{a}, 2 \mathrm{a}}=9.6, J_{1 \mathrm{a}, 1 \mathrm{~b}}=11.6 \mathrm{~Hz}, 1 \mathrm{H}, \mathrm{H}-1 \mathrm{a}\right)$, $3.21\left(\mathrm{ddd}, J_{1 \mathrm{~b}, 2 \mathrm{~b}}=3.4, J_{1 \mathrm{~b}, 2 \mathrm{a}}=9.9, J_{1 \mathrm{a}, 1 \mathrm{~b}}=11.6 \mathrm{~Hz}, 1 \mathrm{H}, \mathrm{H}-1 \mathrm{~b}\right), 2.13\left(\mathrm{dddd}, J_{2 \mathrm{a}, 3}=4.9, J_{2 \mathrm{a}, 1 \mathrm{a}}=9.6, J_{2 \mathrm{a}, 1 \mathrm{~b}}\right.$ $\left.=9.9, J_{2 \mathrm{a}, 2 \mathrm{~b}}=14.1 \mathrm{~Hz}, 1 \mathrm{H}, \mathrm{H}-2 \mathrm{a}\right), 2.05\left(\mathrm{dddd}, J_{2 \mathrm{~b}, 3}=1.5, J_{2 \mathrm{~b}, 1 \mathrm{~b}}=3.4, J_{2 \mathrm{~b}, 1 \mathrm{a}}=7.6, J_{2 \mathrm{a}, 2 \mathrm{~b}}=14.1 \mathrm{~Hz}, 1 \mathrm{H}\right.$, $\mathrm{H}-2 \mathrm{~b}) ;{ }^{13} \mathrm{C}-\mathrm{NMR}\left(125 \mathrm{MHz}, \mathrm{D}_{2} \mathrm{O}\right) \delta 70.8$ (C3), 64.1 (C4), 59.0 (C5), 42.9 (C2), 33.3 (C1). HRMS(ESI) $m / z$ calcd. for $\left[\mathrm{C}_{5} \mathrm{H}_{12} \mathrm{NO}_{2}\right]^{+}: 118.0868$ obsd.:118.0870.

\section{Conclusions}

In summary, we have achieved an efficient, high yielding and diastereoselective protecting-groupfree synthesis of 1,2,4-trideoxy-1,4-imino-L-xylitol. During the course of this work, we were able to illustrate the extension of our Vasella-reductive amination and carbamate annulation methodologies to the synthesis of 2-deoxy aza-sugars. Little is known about the biological profile of 1,2,4-trideoxy-1,4imino-L-xylitol and this is currently under investigation.

\section{Acknowledgements}

The authors would like to acknowledge the financial contribution of the Wellington Medical Research Foundation, the Tertiary Education Commission (Top Achiever Doctoral scholarship, EMD), and Victoria University of Wellington (Post-graduate scholarship, Curtis-Gordon research scholarship, CHP).

\section{References}

1. Borges de Melo, E.; da Silveira Gomes, A.; Carvalho, I. $\alpha$ - and $\beta$-Glucosidase inhibitors: Chemical structure and biological activity. Tetrahedron 2006, 62, 10277-10302.

2. Ganem, B. Inhibitors of carbohydrate-processing enzymes: Design and synthesis of sugar-shaped heterocycles. Acc. Chem. Res. 1996, 29, 340-347.

3. Asano, N.; Nash., R.J.; Molyneux, R.J.; Fleet, G.W. Sugar-mimic glycosidase inhibitors: natural occurrence, biological activity and prospects for therapeutic application. Tetrahedron Asymmetry 2000, 11, 1645-1680. 
4. Watson, A.A.; Fleet, G.W.J.; Asano, N.; Molyneux, R.J.; Nash, R.J. Polyhydroxylated alkaloids natural occurrence and therapeutic applications. Phytochemistry 2001, 56, 265-295.

5. Dwek, R.A.; Butters, T.D.; Platt, F.M.; Zitzmann, N. Targeting glycosylation as a therapeutic approach. Nat. Rev. Drug Discov. 2002, 1, 65-75.

6. Butters, T.D.; Dwek, R.A.; Platt, F.M. Imino sugar inhibitors for treating the lysosomal glycosphingolipidoses. Glycobiology 2005, 15, 43R-53R.

7. Greimel, P.; Spreitz, J.; Stutz, A.E.; Wrodnigg, T.M. Iminosugars and relatives as antiviral and potential anti-infective agents. Curr. Top. Med. Chem. 2003, 3, 513-523.

8. Caines, M.E.C.; Hancock, S.M.; Tarling, C.A.; Wrodnigg, T.M.; Stick, R.V.; Stutz, A.E.; Vasella, A.; Withers, S.G.; Strynadka, N.C.J. The structural basis of glycosidase inhibition by fivemembered iminocyclitols: The clan a glycoside hydrolase endoglycoceramidase as a model system. Angew. Chem. Int. Ed. 2007, 46, 4474-4476.

9. Wrodnigg, T.M.; Steiner, A.J.; Ueberbacher, B.J. Natural and synthetic iminosugars as carbohydrate processing enzyme inhibitors for cancer therapy. Anti-Cancer Agents Med. Chem. 2008, 8, 77-85.

10. Cox, T.; Lachmann, R.; Hollak, C.; Aerts, J.; van Weely, S.; Hrebícek, M.; Platt, F.; Butters, T.; Dwek, R.; Moyses, C.; Gow, I.; Elstein, D.; Zimran, A. Novel oral treatment of Gaucher's disease with $\mathrm{N}$-butyldeoxynojirimycin (OGT 918) to decrease substrate biosynthesis. Lancet 2000, 355, 1481-1485.

11. Dangerfield, E.M.; Timmer, M.S.M.; Stocker, B.L. Total synthesis without protecting groups: Pyrrolidines and cyclic carbamates. Org. Lett. 2009, 11, 535-538.

12. Sobin, B.A.; Tanner, F.W., Jr. Anisomycin, a new anti-protozoan antibiotic. J. Am. Chem. Soc. 1954, 76, 4053.

13. Fleet, G.W.J.; Smith, P.W.; Evans, S.V.; Fellows, L.E. Design, synthesis and preliminary evaluation of a potent $\alpha$-mannosidase inhibitor: 1,4-dideoxy-1,4-imino-D-mannitol. J. Chem. Soc. Chem. Commun. 1984, 1240-1241.

14. Yu, Z.; Sawkar, A.R.; Whalen, L.J.; Wong, C.H.; Kelly, J.W. Isofagomine- and 2,5-anhydro-2,5imino-D-glucitol-based glucocerebrosidase pharmacological chaperones for Gaucher disease intervention. J. Med. Chem. 2007, 50, 94-100.

15. Fleet, G.W.J.; Nicholas, S.J.; Smith, P.W.; Evans, S.V.; Fellows, L.E.; Nash, R.J. Potent competitive inhibition of $\alpha$-galactosidase and $\alpha$-glucosidase activity by 1,4 -dideoxy-1,4iminopentitols: Synthesis of 1,4-dideoxy-1,4-imino-D-lyxitol and of both enantiomers of 1,4dideoxy-1,4-iminoarabinitol. Tetrahedron Lett. 1985, 26, 3127-3130.

16. Nash, R.J.; Bell, E.A.; Williams, J.M. 2-Hydroxymethyl-3,4-dihydroxypyrrolidine in fruits of angylocalyx-boutiqueanus. Phytochemistry 1985, 24, 1620-1622.

17. Saludes, J.P.; Lievens, S.C.; Molinski, T.F. Occurrence of the $\alpha$-glucosidase inhibitor 1,4dideoxy-1,4-imino-D-arabinitol and related iminopentitols in marine sponges. J. Nat. Prod. 2007, $70,436-438$.

18. Hoffer, M. $\alpha$-Thymidin. Chem. Ber. 1960, 93, 2777-2781.

19. Wang, D.; Nugent, W.A. 2-Deoxyribose as a rich source of chiral 5-carbon building blocks. $J$. Org. Chem. 2007, 72, 7307-7312. 
20. Lee, J.H.; Kang, J.E.; Yang, M.S.; Kang, K.Y.; Park, K.H. Efficient synthesis of 3hydroxyprolines and 3-hydroxyprolinols from sugars. Tetrahedron 2001, 57, 10071-10076.

21. Merino, P.; Delso, I.; Tejero, T.; Cardona, F.; Marradi, M.; Faggi, E.; Parmeggiani, C.; Goti, A. Nucleophilic additions to cyclic nitrones en route to iminocyclitols - total syntheses of DMDP, 6-deoxy-DMDP, DAB-1, CYB-3, Nectrisine, and Radicamine B. Eur. J. Org. Chem. 2008, 2929-2947.

22. Mascavage, L.M.; Lu, Q.; Vey, J.; Dalton, D.R.; Carroll, P.J. Enantioselective synthesis of aza sugars from amino acids. 2. The 3-hydroxy-2-hydroxymethylpyrrolidines. J. Org. Chem. 2001, 66, 3621-3626.

23. Jurczak, J.; Prokopowicz, P.; Golebiowski, A. Highly selective synthesis of cis-(2R, 3S)-3hydroxyproline. Tetrahedron Lett. 1993, 34, 7107-7110.

24. Chamberlin, A.R.; Dezube, M.; Dussault, P.; McMills, M.C. Iodocyclization of allylic alcohol derivatives containing internal nucleophiles. Control of stereoselectivity by substituents in the acyclic precursors. J. Am. Chem. Soc. 1983, 105, 5819-5825.

25. Kahn, S.D.; Pau, C.F.; Chamberlin, A.R.; Hehre, W.J. Modeling chemical-reactivity .4. Regiochemistry and stereochemistry of electrophilic additions to allylic double-bonds. J. Am. Chem. Soc. 1987, 109, 650-663.

26. Chamberlin, A.R.; Mulholland, R.L.; Kahn, S.D.; Hehre, W.J. Modeling chemical-reactivity.7. The effect of a change in rate-limiting step on the stereoselectivity of electrophilic addition to allylic alcohols and related chiral alkenes. J. Am. Chem. Soc. 1987, 109, 672-677.

27. Tredwell, M.; Luft, J.A.; Schuler, M.; Tenza, K.; Houk, K.N.; Gouverneur V. Fluorine-directed diastereoselective iodocyclizations. Angew. Chem. Int. Ed. Engl. 2008, 47, 357-360.

28. Bürgi, H.B.; Dunitz, J.D.; Shefter, E. Geometrical reaction coordinates. 2. nucleophilic addition to a carbonyl group. J. Am. Chem. Soc. 1973, 95, 5065-5067.

Sample Availability: Contact the authors.

(C) 2009 by the authors; licensee Molecular Diversity Preservation International, Basel, Switzerland. This article is an open-access article distributed under the terms and conditions of the Creative Commons Attribution license (http://creativecommons.org/licenses/by/3.0/). 